\title{
METABOLISM OF MUCOPOLYSACCHARIDES IN CONNECTIVE TISSUE. II. SYNTHESIS OF GLUCOSAMINE-6-PHOSPHATE *
}

\author{
By ALFRED JAY BOLLET † AND ALLEN SHUSTER
}

\author{
(From the Departments of Preventive Medicine and Internal Medicine, University of Virginia \\ School of Medicine, Charlottesville, Va. and the Department of Medicine, Wayne \\ State University College of Medicine, Detroit, Mich.)
}

(Submitted for publication January 29, 1960; accepted March 31, 1960)

New methods of studying metabolic processes in connective tissue provide opportunity to obtain information concerning enzymatic steps in the synthesis of mucopolysaccharides in that tissue. These techniques supplement studies done in microorganisms and in other tissues (1-3), and allow investigation of phenomena of interest in relation to the diseases of connective tissue at an enzymatic level. Glucosamine and galactosamine are present in the disaccharide repeating units of the mucopolysaccharides of connective tissue. Uridine diphosphoacetylglucosamine has been shown to be the donor of acetylglucosamine in hyaluronate synthesis and the precursor of uridine diphosphoacetylgalactosamine which serves a similar function in chondroitin sulfate synthesis (1). An initial step in the synthesis of uridine diphosphoacetylglucosamine is the synthesis of glucosamine6-phosphate.

The present report concerns the activity of the enzyme involved in the synthesis of glucosamine6-phosphate in connective tissue and liver of rats and in human synovial tissues, as well as investigation of the influence of cortisol and gold compounds on the activity of this enzyme. A comparison of the effects of cortisol on several aspects of connective tissue metabolism has also been made.

\section{METHODS}

Polyvinyl (Ivalon) sponges were inserted under the dorsal skin of male Wistar albino rats weighing $200 \pm$ $50 \mathrm{~g}$, anesthetized with pentobarbital (50 $\mathrm{mg}$ per $\mathrm{kg}$ ). The animals were sacrificed 2 weeks later; the sponges

* This work was supported by grants from the Michigan Chapter of the Arthritis and Rheumatism Foundation and the United States Public Health Service, Research Grant A-3421.

$\dagger$ John and Mary R. Markle Scholar in Medical Sciences. and liver were removed, weighed and homogenized separately. Human synovial tissue obtained at the time of arthrotomy for orthopedic surgery was homogenized within a few minutes after removal.

Fructose-6-phosphate-glutamine transamidase. The activity of this enzyme was determined by a modification of the procedure of Pogell and Gryder (4). Homogenates were made in $0.15 \mathrm{M} \mathrm{KCl}$, with $0.001 \mathrm{M}$ disodium ethylenediamine tetraacetate (EDTA), 0.065 per cent mercaptoethanol, and $0.024 \mathrm{M}$ glutamine, $\mathrm{pH}$ 7.0. Assays were done in a volume of $2 \mathrm{ml}$ containing $20 \mu$ moles of fructose-6-phosphate, $25 \mu$ moles of glutamine and 50 $\mu$ moles of phosphate buffer, $\mathrm{pH} 7.7$. After 15 to $60 \mathrm{~min}$ utes at $37^{\circ} \mathrm{C}$, the incubation mixture was heated at $100^{\circ}$ for 2 minutes, centrifuged, and the hexosamine content of an aliquot of the supernatant solution was determined following conversion to acetylhexosamine by the procedure of Roseman and Daffner (5), using the method of Reissig, Strominger and Leloir (6). Glucosamine, subjected to the same procedure, was used as reference standard. The absorption spectrum of the product of the enzymatic reaction matched that of the reference standard.

Glutamic-oxaloacetic transaminase and glutamic-pyruvic transaminase. Activity of these enzymes was determined using homogenates made in $0.1 \mathrm{M}$ phosphate buffer, $\mathrm{pH}$ 7.5. Glutamic-oxaloacetic transaminase was determined using 0.1 mmole of aspartate, 0.02 mmole of $\alpha$-ketoglutarate and 0.2 mmole of phosphate buffer, $\mathrm{pH}$ 7.5 , in a total volume of $2.0 \mathrm{ml}$. After 20 minutes at $37^{\circ} \mathrm{C}$, the solutions were heat inactivated at $100^{\circ}$ for 2 minutes, centrifuged, and $0.2 \mathrm{ml}$ of supernatant was then added to $0.2 \mathrm{mg}$ reduced diphosphopyridine nucleotide $(\mathrm{DPNH}), 400$ units of malic dehydrogenase (Sigma),

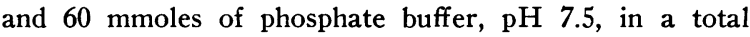
volume of $2.0 \mathrm{ml}$. After incubation for 20 minutes, DPNH disappearance was determined fluorometrically, following the procedure of Lowry, Roberts and Kapphahn (7). Glutamic-pyruvic transaminase was assayed in a similar fashion, using $50 \mu$ moles of alanine and 400 units of lactic dehydrogenase (Sigma) in place of the aspartate and malic dehydrogenase. The amount of homogenate used in each assay was kept within the range which would give zero order reaction and a straight line relationship between the amount of homogenate and the amount of DPNH oxidized. Protein determinations were done by ultraviolet absorption (8). 


\section{RESULTS}

Activity of the transamidase which synthesizes glucosamine-6-phosphate from fructose-6-phosphate and glutamine was demonstrated in liver and in the connective tissue which entered polyvinyl sponges in rats, and in human synovial tissue samples. Expressed as micromoles of hexosamine formed per milligram of protein in the crude homogenate, connective tissue homogenates usually had a slightly greater activity than did liver homogenates from each animal (Table IV). The findings in human synovial tissue are given in Table I. No correlation was found between the level of enzymatic activity and the diagnosis, age of the patient or histological appearance of the

TABLE I

Fructose-6-phosphate-glutamine transamidase activity of human synovial tissue obtained surgically

\begin{tabular}{|c|c|c|c|c|}
\hline Site & Age & Sex & Diagnosis & $\begin{array}{l}\text { Glucosamine } \\
\text { synthesis }\end{array}$ \\
\hline & & & & $\begin{array}{l}\text { pmoles } \\
\times 10^{-4} \\
\mathrm{hr} / \mathrm{mg} \\
\text { protein }\end{array}$ \\
\hline Knee & 67 & $\mathbf{M}$ & $\begin{array}{l}\text { Traumatic arthritis with } \\
\text { effusion }\end{array}$ & 97 \\
\hline Knee & 46 & M & Osteochondritis desiccans & 61 \\
\hline Hip & 40 & $\mathrm{~F}$ & $\begin{array}{l}\text { Aseptic necrosis of femoral } \\
\text { head }\end{array}$ & 56 \\
\hline Elbow & 58 & $\mathbf{M}$ & Traumatic bursitis & 49 \\
\hline Tendon & 33 & $\mathrm{~F}$ & Ganglion & 47 \\
\hline Knee & 31 & M & Fractured patella & 42 \\
\hline Knee & 58 & M & Fractured patella & 37 \\
\hline Knee & 30 & $\mathbf{M}$ & Fractured patella & 22 \\
\hline Elbow & 37 & $\mathbf{M}$ & Traumatic bursitis & 22 \\
\hline Knee & 54 & $\mathbf{F}$ & Traumatic bursitis & 19 \\
\hline Hip & 25 & $\mathrm{~F}$ & $\begin{array}{l}\text { Aseptic necrosis of femoral } \\
\text { head }\end{array}$ & 14 \\
\hline Hip & 56 & M & Ankylosing spondylitis & 6 \\
\hline
\end{tabular}

tissue in a limited group of individuals studied. The lowest value was found in a man with ankylosing spondylitis who was noted to have marked softening of the femoral head at the time of surgery.

Synthesis of hexosamine occurred in connective tissue homogenates with either fructose-6-phosphate or glucose-6-phosphate, but little or no synthesis occurred when other sugars were substituted (Table II). Hexosamine synthesis occurred in liver homogenates with a variety of sugars, although the greatest activity was found with fructose-6-phosphate or mannose-6-phosphate. Ammonium chloride and glutamine were compared as
TABLE II

Comparison of the synthesis of hexosamine by connective tissue homogenates with equimolar amounts of various substrates*

\begin{tabular}{lcr}
\hline \hline & \multicolumn{2}{c}{ Homogenate used } \\
\cline { 2 - 3 } \multicolumn{1}{c}{ Substrate } & $\begin{array}{c}\text { Connective } \\
\text { tissue }\end{array}$ & Liver \\
\hline Fructose-6-phosphate & 100 & 100 \\
Glucose-6-phosphate & 99 & 97 \\
Galactose-6-phosphate & 12 & 70 \\
Mannose-6-phosphate & 15 & 106 \\
Fructose & 0 & 71 \\
Glucose & 0 & 48 \\
Galactose & 0 & 68 \\
Mannose & 0 & 56
\end{tabular}

* Figures are percentage of synthesis with fructose-6phosphate.

donors of the amino groups in both systems; these results were summarized in Table III.

Effect of cortisol (Table IV). Beginning the seventh day after the insertion of the polyvinyl sponges, rats were injected daily with $5 \mathrm{mg}$ of cortisol subcutaneously for one week before sacrifice. Cortisol administration caused a decrease in the weight and protein content of the granuloma. A fall in fructose-6-phosphate-glutamine transamidase activity occurred, but this change was not statistically significant. The glutamicoxaloacetic transaminase activity in the connective tissue rose to a significant extent, but there was no change in the glutamic-pyruvic transaminase activity.

The fall in fructose-6-phosphate-glutamine transamidase activity in the liver was of the same magnitude as that in connective tissue. This dosage of cortisol produced very definite increases in the hepatic glutamic-oxaloacetic and glutamic-pyruvic transaminase activities. Cortisol was not found to influence the activity of these enzymes

TABLE III

Assay of relative effectiveness of glutamine and $\mathrm{NH}_{4} \mathrm{Cl}$ as donors of amine group in glucosamine-6-phosphate synthesis

\begin{tabular}{ccc}
\hline \multicolumn{2}{c}{ Glucosamine synthesis $\left(\mu\right.$ moles $\times 10^{-4} / \mathrm{hr} / \mathrm{mg}$ protein $)$} \\
Homogenate used \\
\cline { 2 - 3 } Donor added & $\begin{array}{c}\text { Connective } \\
\text { tissue }\end{array}$ & Liver \\
\hline Glutamine, 12.5 mmoles & 55.6 & 23.8 \\
NH ${ }_{4} \mathrm{Cl}, 12.5$ mmoles & 17.2 & 15.3 \\
Neither & 11.8 & 19.8 \\
\hline
\end{tabular}


TABLE IV

Effect of cortisol on sponge connective tissue and liver of rats*

\begin{tabular}{|c|c|c|c|c|c|c|c|}
\hline & & \multicolumn{3}{|c|}{ Connective tissue } & \multicolumn{3}{|c|}{ Liver } \\
\hline & & Mean & SEM† & No. & Mean & SEM $\dagger$ & No. \\
\hline Weight of granuloma $(g)$ & $\begin{array}{l}\text { Treated } \\
\text { Control }\end{array}$ & $\begin{array}{l}1.48 \\
1.93\end{array}$ & $\begin{array}{c} \pm 0.07 \\
\pm 0.133 \\
=<0.01\end{array}$ & $\begin{array}{l}12 \\
17\end{array}$ & & & \\
\hline Protein content of granuloma $(m g)$ & $\begin{array}{l}\text { Treated } \\
\text { Control }\end{array}$ & $\begin{array}{l}142 \\
297\end{array}$ & $\begin{array}{l} \pm 26.9 \\
\pm 41.4 \\
=<0.01\end{array}$ & $\begin{array}{l}12 \\
17\end{array}$ & & & \\
\hline $\begin{array}{l}\text { Fructose-6-phosphate-glutamine } \\
\text { transamidase }\end{array}$ & $\begin{array}{l}\text { Treated } \\
\text { Control }\end{array}$ & $\begin{array}{l}29.4 \\
41.9\end{array}$ & $\begin{array}{l} \pm 6.74 \\
\pm 5.03 \\
=<0.1\end{array}$ & $\begin{array}{l}12 \\
17\end{array}$ & $\begin{array}{l}21.6 \\
32.4\end{array}$ & $\begin{array}{l} \pm 5.55 \\
\pm 4.16 \\
=<0.1\end{array}$ & $\begin{array}{l}11 \\
17\end{array}$ \\
\hline Glutamic-oxaloacetic transaminase & $\begin{array}{l}\text { Treated } \\
\text { Control }\end{array}$ & $\begin{array}{l}9.54 \\
6.45\end{array}$ & $\begin{array}{l} \pm 1.35 \\
\pm 0.83 \\
=<0.05\end{array}$ & $\begin{array}{l}11 \\
14\end{array}$ & $\begin{array}{l}73.9 \\
44.5\end{array}$ & $\begin{array}{c} \pm 6.50 \\
\pm 4.95 \\
=<0.01\end{array}$ & $\begin{array}{l}12 \\
14\end{array}$ \\
\hline Glutamic-pyruvic transaminase & $\begin{array}{l}\text { Treated } \\
\text { Control }\end{array}$ & $\begin{array}{l}9.47 \\
8.88\end{array}$ & $\begin{array}{l} \pm 1.45 \\
\pm 1.13 \\
=<0.3\end{array}$ & $\begin{array}{l}11 \\
14\end{array}$ & $\begin{array}{r}15.0 \\
5.1\end{array}$ & $\begin{aligned} & \pm 1.92 \\
\pm 0.80 & \\
= & <0.001\end{aligned}$ & $\begin{array}{l}12 \\
14\end{array}$ \\
\hline
\end{tabular}

* Data for enzyme activities are in the following units: fructose-6-phosphate transamidase, $\mu \mathrm{moles} \times 10^{-4} / \mathrm{hr} / \mathrm{mg}$ protein; glutamic-oxaloacetic transaminase, $\mu$ moles $/ \mathrm{hr} / \mathrm{mg}$ protein; glutamic-pyruvic transaminase, $\mu \mathrm{moles} / \mathrm{hr} / \mathrm{mg}$ protein for liver and $\mu$ moles $\times 10^{-2} / \mathrm{hr} / \mathrm{mg}$ protein for connective tissue.

$\dagger$ Standard error of the mean.

in connective tissue or in liver homogenates when added in vitro.

Effect of gold chloride in vitro. Since EDTA and mercaptoethanol were necessary to protect the fructose-6-phosphate-glutamine transamidase in tissue homogenates, it seemed possible that gold salts might influence the activity of the enzyme. Homogenates made in medium containing EDTA, but no mercaptoethanol, were incubated with and without a series of potential inhibitors. Gold chloride inhibited the activity of this enzyme in connective tissue homogenates in a lower concentration than in liver homogenates (Table V). Other sulfhydryl reactants such as iodoacetamide, iodobenzoic and $p$-chloromecuribenzoate were also found to inhibit the activity of this enzyme in connective tissue homogenates, although the concentration of these substances needed to give 50 per cent inhibition was ten times that found for gold chloride.

The effect of gold sodium thiomalate in vivo. One week after insertion of sponges, $10 \mathrm{mg}$ of gold sodium thiomalate (Myochrysine) was administered subcutaneously. Seven to ten days later enzyme assays were performed. A marked decrease in the activity of the fructose-6-phosphate-glutamine transamidase was found in the connective tissue homogenates, but no effect was noted on the activity of the enzyme in liver ho- mogenates obtained from the same animals (Table VI).

The acid mucopolysaccharide concentration of the sponge connective tissue in three of the animals injected with gold sodium thiomalate was de-

TABLE V

Effect of gold chloride and other inhibitors on the activity of the fructose-6-phosphate-glutamine transamidase in rat tissue homogenates

\begin{tabular}{lccr}
\hline & & \multicolumn{2}{c}{ Per cent inhibition } \\
\cline { 3 - 4 } & $\begin{array}{c}\text { Molarity } \\
\left(\times 10^{-5}\right)\end{array}$ & $\begin{array}{c}\text { Connective } \\
\text { tissue }\end{array}$ & Liver \\
\hline Gold chloride & 500 & 100 & 100 \\
& 50 & 100 & 89 \\
& 5 & 84 & 27 \\
& 3.75 & 38 & \\
Iodoacetamide & 2.5 & 24 & 5 \\
& 1.25 & 16 & 6 \\
& 0.5 & 0 & \\
& 500 & 100 & 81 \\
& 50 & 56 & 9 \\
& 37.5 & 48 & \\
& 25 & 33 & 12 \\
& 12.5 & 0 & 6 \\
& 5 & & 0
\end{tabular}

$\begin{array}{lrr}\text { Iodobenzoate } & 50 & 54 \\ & 25 & 31 \\ & 5 & 6 \\ \text { p-Chloromercuri- } & 50 & 52 \\ \text { benzoate } & 25 & 42 \\ & 5 & 26\end{array}$


TABLE VI

Effect of gold sodium thiomalate administration on fructose-6-phosphate-glutamine transamidase in rats*

\begin{tabular}{|c|c|c|c|c|c|c|}
\hline & \multicolumn{3}{|c|}{ Connective tissue } & \multicolumn{3}{|c|}{ Liver } \\
\hline & Mean & SEM† & No. & Mean & SEM & No. \\
\hline $\begin{array}{l}\text { Treated } \\
\text { Control }\end{array}$ & $\begin{array}{c}12.9 \\
41.9 \\
p=\end{array}$ & $\begin{array}{l} \pm 3.04 \\
\pm 5.03 \\
<0.001\end{array}$ & $\begin{array}{l}11 \\
17\end{array}$ & $\begin{array}{l}31.5 \\
32.4\end{array}$ & $\begin{array}{l} \pm 3.48 \\
\pm 4.16\end{array}$ & $\begin{array}{l}11 \\
17\end{array}$ \\
\hline
\end{tabular}

* Activity is expressed as $\mu$ moles $\times 10^{-4} / \mathrm{hr} / \mathrm{mg}$ protein. † Standard error of the mean.

termined by a method previously described (9). Expressed as uronic acid content of the acid mucopolysaccharide fraction, a decrease from an average of $85 \mathrm{mg}$ per $100 \mathrm{~g}$ of dry connective tissue in control animals to $52 \mathrm{mg}$ per $100 \mathrm{~g}$ in the treated animals was noted.

\section{DISCUSSION}

Many of the characteristics of the enzyme involved in the synthesis of glucosamine-6-phosphate were demonstrated comparatively easily in homogenates of the granulation tissue which formed in polyvinyl sponges. Similar homogenates of liver tissue contained a lower activity of the fructose-6-phosphate-glutamine transamidase and a relatively greater concentration of other enzymes which interfered with the characterization of the substrates of the transamidase.

Cortisone and cortisol have been shown to inhibit connective tissue growth, fibril formation, sulfate fixation and oxygen consumption (10). An objective of this study was to determine if adrenal steroids uniformly inhibit all metabolic activities of connective tissue, or whether selective effects on certain metabolic functions occur. The glutamic-pyruvic and glutamic-oxaloacetic transaminases were studied in connective tissue since an increase in the activities of these enzymes in the liver of rats given cortisol has been reported $(11,12)$. Our finding of an increase in glutamicoxaloacetic transaminase activity in connective tissue after cortisol administration indicates that this agent does not uniformly inhibit all metabolic activities in that tissue. Cortisol and gold sodium thiomalate were found to have different effects on liver than on connective tissue metabolism: the former increased glutamic-pyruvic transaminase activity only in the liver, while the latter depressed fructose-6-phosphate-glutamine transamidase activity only in connective tissue. These findings indicate the need for direct study of connective tissue metabolism.

It has been assumed that gold compounds exert their effects on patients with rheumatoid arthritis through inhibition of enzymes with labile sulfhydryl groups (13). Evidence has been obtained in animals that the effects of gold compounds used therapeutically are due to the gold content of these agents and not to the rest of the molecule, regardless of the type of linkage involved $(14,15)$. The need to protect the enzyme which synthesizes glucosamine-6-phosphate from sulfhydryl inhibitors in vitro led to assay of gold compounds on the activity of this enzyme. Concentrations of gold which caused inhibition in connective tissue homogenates were of the order of magnitude found in the serum of patients receiving gold compounds for therapy of rheumatoid arthritis (16).

\section{SUM M ARY}

The transamidase, which synthesizes glucosamine-6-phosphate, and the glutamic-oxaloacetic and glutamic-pyruvic transaminases were studied in connective tissue and liver of rats, and in human synovial tissue. Cortisol was found to cause a moderate diminution in the activity of the fructose-6-phosphate-glutamine transamidase, but caused an increase in the glutamic-oxaloacetic transaminase activity of connective tissue homogenates. No change in the glutamic-pyruvic transaminase activity occurred. In the liver, cortisol administration caused a moderate decrease in fructose-6-phosphate-glutamine transamidase activity and marked increase in glutamic-oxaloacetic and glutamic-pyruvic transaminase activities. Gold chloride inhibited the activity of the transamidase which synthesizes glucosamine-6-phosphate in connective tissue homogenates in vitro in concentrations which are found in the serum of patients receiving gold compounds therapeutically. Gold sodium thiomalate administration in vivo resulted in decrease in the activity of this enzyme in connective tissue but not in liver. 


\section{REFERENCES}

1. Roseman, S. Metabolism of connective tissue in Annual Review of Biochemistry. Palo Alto, Annual Reviews, Inc., 1959, vol. 28, p. 545.

2. Bollet, A. J., Goodwin, J. F., and Brown, A. K. Metabolism of mucopolysaccharides in connective tissue. I. Studies of enzymes involved in glucuronide metabolism. J. clin. Invest. 1959, 38, 451.

3. Kizer, D. E., and McCoy, T. A. The synthesis of hexosamine in tumor homogenates. Cancer Res. 1959, 19, 307.

4. Pogell, B. M., and Gryder, R. M. Enzymatic synthesis of glucosamine-6-phosphate in rat liver. J. biol. Chem. 1957, 228, 701.

5. Roseman, S., and Daffner, I. Colorimetric method for determination of glucosamine and galactosamine. Analyt. Chem. 1956, 28, 1743.

6. Reissig, J. L., Strominger, J., and Leloir, L. F. A modified colorimetric method for the estimation of N-acetylamino sugars. J. biol. Chem. 1955, 217, 959.

7. Lowry, O. H., Roberts, N. R., and Kapphahn, J. I. The fluorimetric measurement of pyridine nucleotides. J. biol. Chem. 1957, 224, 1047.

8. Layne, E. Spectrophotometric and turbidimetric methods for measuring proteins in Methods in Enzymology, S. P. Colowick and N. O. Kaplan, Eds. New York, Academic Press Inc., 1955, vol. III, p. 447.
9. Bollet, A. J. The measurement of tissue acid mucopolysaccharides. J. clin. Invest. 1958, 37, 858.

10. Taubenhaus, M. Hormonal influences on granulation tissue formation in The Healing of Wounds, Martin B. Williamson, Ed. New York, McGraw-Hill, 1957, p. 113.

11. Rosen, F., Roberts, N. R., Budnick, L. E., and Nichol, C. A. An enzymatic basis for the gluconeogenic action of hydrocortisone. Science 1958, 127, 287.

12. Rosen, F., Roberts, N. R., and Nichol, C. A. Glucocortico-steroids and transamidase activity. I. Increased activity of glutamic-pyruvic transaminase in four conditions associated with gluconeogenesis. J. biol. Chem. 1959, 234, 476.

13. Freyberg, R. H., Block, W. D., and Levey, S. Metabolism, toxicity and manner of action of gold compounds used in the treatment of arthritis. J. clin. Invest. 1951, 20, 401.

14. Preston, W. S., Block, W. D., and Freyberg, R. H. Chemotherapy of progressive arthritis of mice. I. Role of sulfur in gold-containing compounds. Proc. Soc. exp. Biol. (N. Y.) 1942, 50, 253.

15. Denko, C., and Anderson, A. K. Studies on the toxicity of gold compounds in rats. J. Lab. clin. Med. 1944, 29, 1168.

16. Goodwin, J. F., and Bollet, A. J. The microdetermination of gold in the serum and urine of patients receiving chrysotherapy. J. Lab. clin. Med. In press. 